\title{
Major Vault Protein, a Candidate Gene in 16p11.2 Microdeletion Syndrome, Is Required for the Homeostatic Regulation of Visual Cortical Plasticity
}

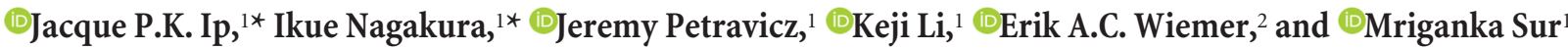 \\ ${ }^{1}$ Department of Brain and Cognitive Sciences, Picower Institute for Learning and Memory, Massachusetts Institute of Technology, Cambridge, \\ Massachusetts 02139 and 2Department of Medical Oncology, Erasmus MC Cancer Institute, Erasmus University Medical Center, 3015 CN Rotterdam, The \\ Netherlands
}

Microdeletion of a region in chromosome 16p11.2 increases susceptibility to autism. Although this region contains exons of 29 genes, disrupting only a small segment of the region, which spans five genes, is sufficient to cause autistic traits. One candidate gene in this critical segment is $M V P$, which encodes for the major vault protein (MVP) that has been implicated in regulation of cellular transport mechanisms. MVP expression levels in $M V P^{+/-}$mice closely phenocopy those of $16 \mathrm{p} 11.2$ mutant mice, suggesting that $M V P^{+/-}$mice may serve as a model of MVP function in 16p11.2 microdeletion. Here we show that MVP regulates the homeostatic component of ocular dominance (OD) plasticity in primary visual cortex. $M V P^{+/-}$mice of both sexes show impairment in strengthening of open-eye responses after several days of monocular deprivation (MD), whereas closed-eye responses are weakened as normal, resulting in reduced overall OD plasticity. The frequency of miniature EPSCs (mEPSCs) in pyramidal neurons is decreased in $M V P^{+/-}$mice after extended MD, suggesting a reduction of functional synapses. Correspondingly, upregulation of surface GluA1 AMPA receptors is reduced in $M V P^{+/-}$mice after extended MD, and is accompanied by altered expression of STAT1 and phosphorylated ERK, which have been previously implicated in OD plasticity. Normalization of STAT1 levels by introducing STAT1 shRNA rescues surface GluA1 and open-eye responses, implicating STAT1 as a downstream effector of MVP. These findings demonstrate a specific role for MVP as a key molecule influencing the homeostatic component of activity-dependent synaptic plasticity, and potentially the corresponding phenotypes of 16p11.2 microdeletion syndrome.

Key words: autism spectrum disorder; glutamate receptors; ocular dominance plasticity; signaling molecules; synapse development; visual cortex

\section{Significance Statement}

Major vault protein (MVP), a candidate gene in 16p11.2 microdeletion syndrome, has been implicated in the regulation of several cellular processes including transport mechanisms and scaffold signaling. However, its role in brain function and plasticity remains unknown. In this study, we identified MVP as an important regulator of the homeostatic component of experiencedependent plasticity, via regulation of STAT1 and ERK signaling. This study helps reveal a new mechanism for an autism-related gene in brain function, and suggests a broader role for neuro-immune interactions in circuit level plasticity. Importantly, our findings might explain specific components of the pathophysiology of $16 \mathrm{p} 11.2$ microdeletion syndrome.

\section{Introduction}

Microdeletion of a region in chromosome $16 \mathrm{p} 11.2$ increases susceptibility to autism spectrum disorder (ASD) and accounts for

Received July 18, 2017; revised Feb. 17, 2018; accepted March 2, 2018.

Author contributions: K.L. edited the paper; J.P.K.I., I.N., and M.S. designed research; J.P.K.I., I.N., J.P., and K.L. performed research; E.A.C.W. contributed unpublished reagents/analytic tools; J.P.K.I., I.N., J.P., and K.L. analyzed data; J.P.K.I., I.N., and M.S. wrote the paper.

This work was supported by Human Frontier Science Program Long-Term Fellowship (J.P.K.I), NIH Grants MH085802 and EY007023 (M.S.), Simons Postdoctoral Fellowship (I.N.), and the Simons Foundation Autism Research Initiative through the Simons (enter for the Social Brain, MIT (M.S.). We thank Bess Rosen for technical assistance. up to $1 \%$ of the ASD population (Malhotra and Sebat, 2012). Patients carrying this microdeletion exhibit cognitive disability, language delay, ASD, and seizures (Fernandez et al., 2010; Hanson et al., 2015). Deletion of the entire 16p11.2 region in mice

\footnotetext{
The authors declare no competing financial interests.

*J.P.K.I. and I.N. contributed equally to this work.

Correspondence should be addressed to Mriganka Sur, Department of Brain and Cognitive Sciences, Picower Institute for Learning and Memory, Massachusetts Institute of Technology, 77 Massachusetts Avenue, Cambridge, MA 02139. E-mail:msur@mit.edu.

DOI:10.1523/JNEUROSCI.2034-17.2018

Copyright $@ 2018$ the authors $\quad 0270-6474 / 18 / 383890-11 \$ 15.00 / 0$
} 
leads to diverse phenotypes, including hyperactivity, deficits in contextual conditioning and novel object recognition (Horev et al., 2011; Portmann et al., 2014; Tian et al., 2015). Although 16 p11.2 microdeletion commonly leads to haploinsufficiency of 29 genes, disrupting only a small segment of this region, which spans five genes, is sufficient to cause autistic traits (Crepel et al., 2011). One candidate gene in this critical segment is $M V P$, which encodes for the major vault protein (MVP).

MVP is the main structural component of large cellular ribonucleoparticles termed vaults. Vaults, weighing $13 \mathrm{MDa}$, are considered to be involved in nucleocytoplasmic transport (Berger et al., 2009). MVP, also known as lung resistance-related protein (LRP), is upregulated in a number of tumors and implicated in drug resistance (Mossink et al., 2003b; Berger et al., 2009). However, very little is known about its function in the CNS. MVP is required for brain development and synapse formation in invertebrate species (Paspalas et al., 2009; Blaker-Lee et al., 2012; Pan et al., 2013). It has been suggested that MVP may be a regulator of multiple intracellular signaling pathways, several of which are known to mediate aspects of synaptic plasticity and function (Kolli et al., 2004; Chung and Eng, 2005; Kim et al., 2006; Steiner et al., 2006).

Many genes that confer risk for ASD affect synaptic and circuit plasticity during development (Sahin and Sur, 2015). Ocular dominance (OD) plasticity in the primary visual cortex (V1), particularly during a developmental critical period, is a well established model for understanding experience-dependent functional changes in cortical circuits (Hubel and Wiesel, 1970; Gordon and Stryker, 1996; Bear, 2003; Hensch, 2005). Monocular deprivation (MD) by suturing the eyelids of one eye leads to physiological reduction of cortical responses to the deprived (closed) eye, subsequently followed by strengthening of responses to the nondeprived (open) eye (Frenkel and Bear, 2004). Despite no change in visual drive, the strengthening of the non-deprived eye represents an internally driven homeostatic response resulting from a change in eye-specific cortical drive (Turrigiano and Nelson, 2004; Espinosa and Stryker, 2012; Cooke and Bear, 2014). Homeostatic synaptic plasticity is particularly pronounced in developing cortical neurons in vitro (Gainey et al., 2009; Qiu et al., 2012). In V1, activity-induced changes in neurons involve feedforward, Hebbian changes together with feedback, homeostatic changes, which are mediated by key molecular pathways (Tropea et al., 2009b; Sur et al., 2013; Pulimood et al., 2017). Deficits in plasticity due to alterations in ASD genes may fundamentally involve deficits in homeostatic mechanisms of plasticity (Nelson and Valakh, 2015).

Here, we investigated the role of MVP in experience-dependent cortical plasticity in mouse V1. We found that MVP heterozygous deletion $\left(\mathrm{MVP}^{+/-}\right)$mice show impairment in strengthening of open-eye responses after several days of $\mathrm{MD}$, whereas closed-eye responses were weakened as normal, resulting in reduced overall OD plasticity. The frequency of mEPSCs was decreased in $M V P^{+/-}$ mice, suggesting a reduction of functional synapses. We also found reduced levels of surface GluAl in $\mathrm{MVP}^{+/-}$mice after extended MD, accompanied by altered expression of STAT1 and phosphorylated ERK in $M V P^{+/-}$mice, both of which are known to mediate OD plasticity (Di Cristo et al., 2001; Nagakura et al., 2014). Furthermore, normalization of STAT1 levels was sufficient to partially restore surface GluA1 expression and open-eye responses in MVP-knockdown V1 after $7 \mathrm{~d}$ MD, demonstrating a mechanistic link between MVP, STAT1, GluA1 surface expression, and OD plasticity. Collectively, these findings identify MVP as an important regulator of the homeostatic component of experience- dependent plasticity, and help explain the plasticity deficits previously described in mouse models of $16 \mathrm{p} 11.2$ deletion syndrome.

\section{Materials and Methods}

Animals. $\mathrm{MVP}^{+/-}$mice on a C57BL/6 background (Mossink et al., 2002) were crossed with $M V P^{+/+}$mice. The litters were genotyped and maintained in their home cage until experiments. Age-matched $M V P^{+/+}$littermates were used as wild-type (WT) controls. Both male and female mice were used in this study and we found no difference between data derived from male and female mice.

Monocular deprivation. MD was performed by eyelid suture. Animals [aged approximately postnatal day (P)25-P28] were anesthetized with isoflurane $(2-4 \%)$, and the eyelid margins were trimmed. Upper and lower eyelids were closed with sutures and the eyelids were examined every day to make sure that they were closed for the duration of the experiment. MD lasted either $4 \mathrm{~d}$ (short-term MD) or $7 \mathrm{~d}$ (longer-term or extended MD). Sutures were removed and the closed eye was reopened under anesthesia before optical imaging experiments to assess the effects of MD on V1 responses.

Anterograde labeling of retinal ganglion axons. Mice at the above ages were anesthetized with isoflurane. To label retinal ganglion cell axons within the lateral geniculate nucleus (LGN), $2 \mu \mathrm{l}$ of cholera toxin subunit B (CTB) conjugated to AlexaFluor 488 was injected into one eye and AlexaFluor 594 into the other eye $(1 \mathrm{mg} / \mathrm{ml}$; Invitrogen). After $6 \mathrm{~d}$, animals were perfused, the brains were removed and postfixed overnight at $4^{\circ} \mathrm{C}$, and $40 \mu \mathrm{m}$ coronal sections were cut with a vibratome (VT1200S; Leica). Sections were mounted on glass slides and coverslipped for imaging on a Leica SP8 confocal microscope.

Optical imaging of intrinsic signals. Optical imaging was performed as previously described (Nagakura et al., 2014). Mice were anesthetized with urethane $(1.5 \mathrm{mg} / \mathrm{g}$, i.p.) and chlorprothixene $(10 \mathrm{mg} / \mathrm{kg}$, i.p.) or with isoflurane $(2-4 \%)$. The skin was removed and the skull was exposed over V1. A head plate was used to fix the head under the setup and minimize head movements. The cortex was covered with agarose solution (1.5\%) and a glass coverslip. Red light $(630 \mathrm{~nm})$ was used to illuminate the cortical surface, and the change of luminance was captured by a CCD camera (Cascade 512B; Roper Scientific) during the presentation of visual stimuli. An elongated horizontal white bar $\left(9^{\circ} \times 72^{\circ}\right)$ over a uniformly gray background was drifted upward continuously through the peripheral-central dimension of the visual field. After moving to the last position, the bar would jump back to the initial position and start another cycle of movement; therefore, the chosen region of visual space $\left(72^{\circ} \times 72^{\circ}\right)$ was stimulated in a periodic manner $(12 \mathrm{~s} / \mathrm{cycle})$. Images of the visual cortex were continuously captured at the rate of 18 frames/s during each stimulus session of $22 \mathrm{~min}$. A temporal high-pass filter (135 frames) was applied to remove slow noise components, after which the temporal fast Fourier transform (FFT) component at the stimulus frequency $\left(9 s^{-1}\right)$ was calculated pixel by pixel from the whole set of images using custom MATLAB scripts. The amplitude of the FFT component was used to measure the strength of visually driven response for each eye, and the OD index (ODI) was derived from the response $(\mathrm{R})$ of each eye at each pixel as ODI $=\left(\mathrm{R}_{\text {contra }}-\mathrm{R}_{\mathrm{ipsi}}\right) /\left(\mathrm{R}_{\text {contra }}+\mathrm{R}_{\mathrm{ipsi}}\right)$. The binocular zone was defined as the cortical region that was driven by both eyes. The response amplitude for each eye was defined as fractional changes in reflectance over baseline reflectance $\left(\Delta R / R \times 10^{-3}\right)$, and the top $50 \%$ pixels were analyzed to avoid background contamination. In the rescue experiment involving knockdown of MVP and STAT1, we focused on the relative activity of ipsilateral eye responses as a measure of homeostatic plasticity, and the ipsilateral eye response was normalized to the contralateral eye response.

Western blot measurements. V1 contralateral to the deprived eye was removed and snap-frozen with dry ice. The tissues were homogenized in RIPA buffer (Invitrogen) containing proteinase and phosphatase inhibitors (Roche). For Western blots, equal amounts of protein were loaded on a precast gel and transferred to a PVDF membrane. The membrane was blotted with an antiserum raised against human MVP (Mossink et al., 2003a), MVP (OAGA01032, Aviva Systems Biology), HPRT (ab133232, 
Abcam), histone H3 (9715, Cell Signaling Technology), pERK (4370, Cell Signaling Technology), ERK (9102, Cell Signaling Technology), pAkt (9275, Cell Signaling Technology), Akt (9272, Cell Signaling Technology), pJAK1 (3331, Cell Signaling Technology), JAK1 (3332, Cell Signaling Technology), STAT1 $\alpha$ (ab2071, Abcam), $\alpha$-tubulin (9026, Sigma-Aldrich), GAPDH (ab9484, Abcam), GluA1 (04-855, clone C3T, Millipore), and panCadherin (ab6529, Abcam). Cytosolic and nuclear fractionation was performed using the Nuclear/Cytosol Extraction Kit (K266-25, BioVision).

Immunohistochemistry and colocalization analysis. Adult mouse brains were fixed (4\% PFA) and cryoprotected in $20 \%$ and $30 \%$ sucrose solutions, respectively, overnight. Fixed brains were sliced on a cryostat (Leica, CM $3050 \mathrm{~S}$ ) into $20 \mu \mathrm{M}$ sections. Primary staining was performed overnight at $4^{\circ} \mathrm{C}$ and secondary at room temperature for $1 \mathrm{~h}$ (AlexaFluor, Invitrogen). Primary antibodies used were as follows: Ms $\alpha$ Satb2 (Abcam; 1:200); Rabbit $\alpha$ MVP (Abcam; 1:200). Coverslips were affixed with ProLong Gold antifade reagent with DAPI (Life Technologies) and $z$-stack images were acquired using a Leica TCS SP8. Colocalization analysis was performed on maximum projection images using the Cell Counter tools in ImageJ software, and visually assessing the number of MVP-positive cell bodies (AlexaFluor 488), which coexpressed SATB2 (AlexaFluor 594).

Cell-surface biotinylation assay. The levels of cell surface GluA1 were measured using a biotinylation assay as described previously (Nagakura et al., 2014). Briefly, mice were anesthetized using isoflurane (2-4\%), and the brain was immediately dissected. A vibratome was used to cut $300 \mu \mathrm{m}$ coronal sections that contain V1. Slices were then incubated in $100 \mu \mathrm{M}$ S-NHS-SS-biotin (Sigma-Aldrich) for $45 \mathrm{~min}$ on ice. The superficial layers of V1 were microdissected and homogenized in RIPA buffer with protease inhibitors. The homogenate was centrifuged at $4^{\circ} \mathrm{C}$, and the supernatant was incubated with streptavidin beads (ThermoFisher Scientific) overnight at $4^{\circ} \mathrm{C}$. The samples were then processed for Western blotting.

Slice electrophysiology. Mice were anesthetized with isoflurane. The brain was rapidly removed and sliced coronally at a thickness of $300 \mu \mathrm{m}$ with a vibratome in slicing buffer (in mм: 130 choline chloride, 25 glucose, $1.25 \mathrm{NaH}_{2} \mathrm{PO}_{4}, 26 \mathrm{NaCHO}_{3}, 2.5 \mathrm{KCl}, 7 \mathrm{MgCl}_{2}$, and $0.5 \mathrm{CaCl}_{2}$ ) bubbled with $95 \% \mathrm{O}_{2}$ and $5 \% \mathrm{CO}_{2}$. Slices were given a minimum of $60 \mathrm{~min}$ of incubation in room-temperature ACSF (in mM: $130 \mathrm{NaCl}, 10$ glucose, $1.25 \mathrm{NaH}_{2} \mathrm{PO}_{4}, 24 \mathrm{NaCHO}_{3}, 3.5 \mathrm{KCl}, 2.5 \mathrm{CaCl}_{2}$, and $1.5 \mathrm{MgCl}_{2}$ ) before patching. For recording of AMPA receptor (AMPAR)-mediated mEPSCs, whole-cell patch-clamp of layer II/III pyramidal neurons in the binocular region of $\mathrm{V} 1$ was performed using pipettes (4-7 M $\Omega$ resistance) filled with an internal solution (in mM: $100 \mathrm{~K}$-gluconate, $20 \mathrm{KCl}$, 0.5 EGTA, $10 \mathrm{NaCl}, 10 \mathrm{Na}$-phosphocreatine, $4 \mathrm{Mg}$-ATP, $0.3 \mathrm{Na}$-GTP, and 10 HEPES, pH 7.2-7.3 with $1 \mathrm{~m} \mathrm{KOH})$. Neurons were recorded at room temperature $\left(25^{\circ} \mathrm{C}\right)$ in ACSF containing $1 \mu \mathrm{M}$ TTX, $50 \mu \mathrm{M}$ AP-5, and $50 \mu \mathrm{M}$ picrotoxin to isolate AMPAR-mediated currents and voltageclamped at a membrane potential of $-70 \mathrm{mV}$. mEPSCs were recorded using a MultiClamp 700B amplifier (Molecular Devices) at $10 \mathrm{kHz}$, filtered at $2 \mathrm{kHz}$, and analyzed with Clampfit 10.2 software (Molecular Devices). Whole-cell membrane currents were recorded for at least 10 min. For detection of mEPSCs, a detection template for each cell was constructed from four to six events intrinsic to each recording. Traces were analyzed in template search mode in Clampfit 10.2, with a template match threshold of 4-4.5 to reduce false-positives. All events were detected automatically and edited after detection by eye to remove events that were erroneous matches or duplicate events. All mEPSC events were included in the analysis of event parameters.

Virus injection and microdissection. Virus injection was performed using P14 C57BL/6 mice. Validated adeno-associated virus (AAV) constructs targeting mouse MVP (AAV5-GFP-U6-m-MVP-shRNA) and mouse STAT1 (AAV5-RFP-U6-mSTAT1-shRNA) and their scrambled controls were obtained from Vector BioLabs. The viral vectors were delivered to the binocular zone of the visual cortex in mice $(0.5 \mathrm{~mm}$ rostral to lambda and $3 \mathrm{~mm}$ lateral to the midline), and the mice were returned to their home cages for 2 weeks before eyelid suture surgery. After $7 \mathrm{~d}$ $\mathrm{MD}$, the GFP $+/ \mathrm{RFP}+\mathrm{V} 1$ region was microdissected under a fluorescence microscope and subsequently subjected to cell-surface biotinylation assay.
Experimental design and statistical analyses. Both male and female mice were used throughout the study. The number of animals or brain slices used in each experiment is noted in the figure legend. A two-tailed unpaired Student's $t$ test was used for comparisons between two means (see Figs. 1, 2, 4, 5). For comparing more than two means (see Figs. 2, 3), a one-way or two-way ANOVA was used, followed by post hoc pairwise comparisons (Bonferroni correction or Tukey's test). For comparing cumulative probability distributions (see Fig. 3), Kolmogorov-Smirnov test was used. All averaged data are presented as mean \pm SEM.

\section{Results}

\section{MVP expression in visual cortex during development}

We first examined developmental changes in the expression of MVP protein in V1. The protein level of MVP began to increase after eye opening (P11), became significantly higher during the peak of the critical period for OD plasticity (P28; $t$ test, $p=0.031$, P28 vs P11; Fig. $1 A, B)$, and remained high through adulthood (ages $>$ P100; $t$ test, $p=0.047, \mathrm{P} 100$ vs P11), suggesting that expression of MVP is developmentally regulated and visual experience may drive its expression. To determine whether MVP is regulated by visual experience, we examined MVP expression after MD (Fig. 1C,D). During the critical period, the levels of MVP were significantly increased after $7 \mathrm{~d}$ MD ( $t$ test, $p=0.0077$, vs no MD). Because previous studies showed that MVP was localized in both the cytoplasm and nucleus (Chung et al., 2005; Steiner et al., 2006; Peng et al., 2016), we next examined the distribution of MVP in both fractions after $7 \mathrm{~d}$ MD. From the fractionation assay comparing cytosolic/nuclear compartments, we found that MVP level was upregulated in both cytosolic and nuclear fractions with no change in the cytosolic/nuclear ratio of MVP after $7 \mathrm{~d}$ MD, suggesting that the upregulation of MVP occurs in both fractions after $7 \mathrm{~d} \mathrm{MD}$ (Fig. $1 C-E$ ). This upregulation of MVP after MD may suggest a role for MVP in OD plasticity. Immunohistochemical analysis showed that MVP was highly expressed across cortical layers and colocalized with the excitatory neuronal marker SATB2 (Huang et al., 2013; Fig. $1 \mathrm{~J}, \mathrm{~K})$. Interestingly, MVP immunoreactivity was found in both nuclei and neurites (Fig. $1 K$ ). To determine the functional roles of MVP in cortical plasticity and its potential role in $16 \mathrm{p} 11.2$ microdeletion syndrome, we examined MVP mutant mice and confirmed that the expression of MVP in heterozygous deletion $\left(\mathrm{MVP}^{+/-}\right)$mice is $\sim 30 \%$ of expression in WT mice ( $t$ test, $p=$ 0.0154 ; Fig. $1 F, G)$, which is similar to the expression level of MVP in 16p11.2 microdeletion mice ( $t$ test, $p=0.0152$; Fig. 1 H, ; cf. Tian et al., 2015). [The 16p11.2 microdeletion mice were engineered to be heterozygous null at the region of chromosome $7 \mathrm{qF} 3$, which is homologous to human chromosome $16 \mathrm{p} 11.2$ (Horev et al., 2011)]. Collectively, our results demonstrate that MVP expression is developmentally regulated and that it is expressed in excitatory neurons across all cortical layers. Because expression of MVP in $M V P^{+/-}$mice was similar to that in 16 p11.2 microdeletion mice, we decided to investigate the functional role of MVP using $M V P^{+/-}$mice.

\section{$M V P^{+/-}$mice show reduced OD plasticity without strengthening of open-eye responses}

With its prominent expression during the critical period, we hypothesized that MVP has a role in experience-dependent visual cortex plasticity. To determine the role of MVP in synaptic and circuit plasticity, we measured OD plasticity in V1 (Fig. $2 A$ ). We used optical imaging of intrinsic signals to measure eye-specific responses after suturing the contralateral eye for either $4 \mathrm{~d}$ or $7 \mathrm{~d}$ during the critical period. In WT mice, $7 \mathrm{~d}$ MD led to a significant decrease in contralateral (closed) eye responses ( $t$ test, $p=0.0481$ ), 

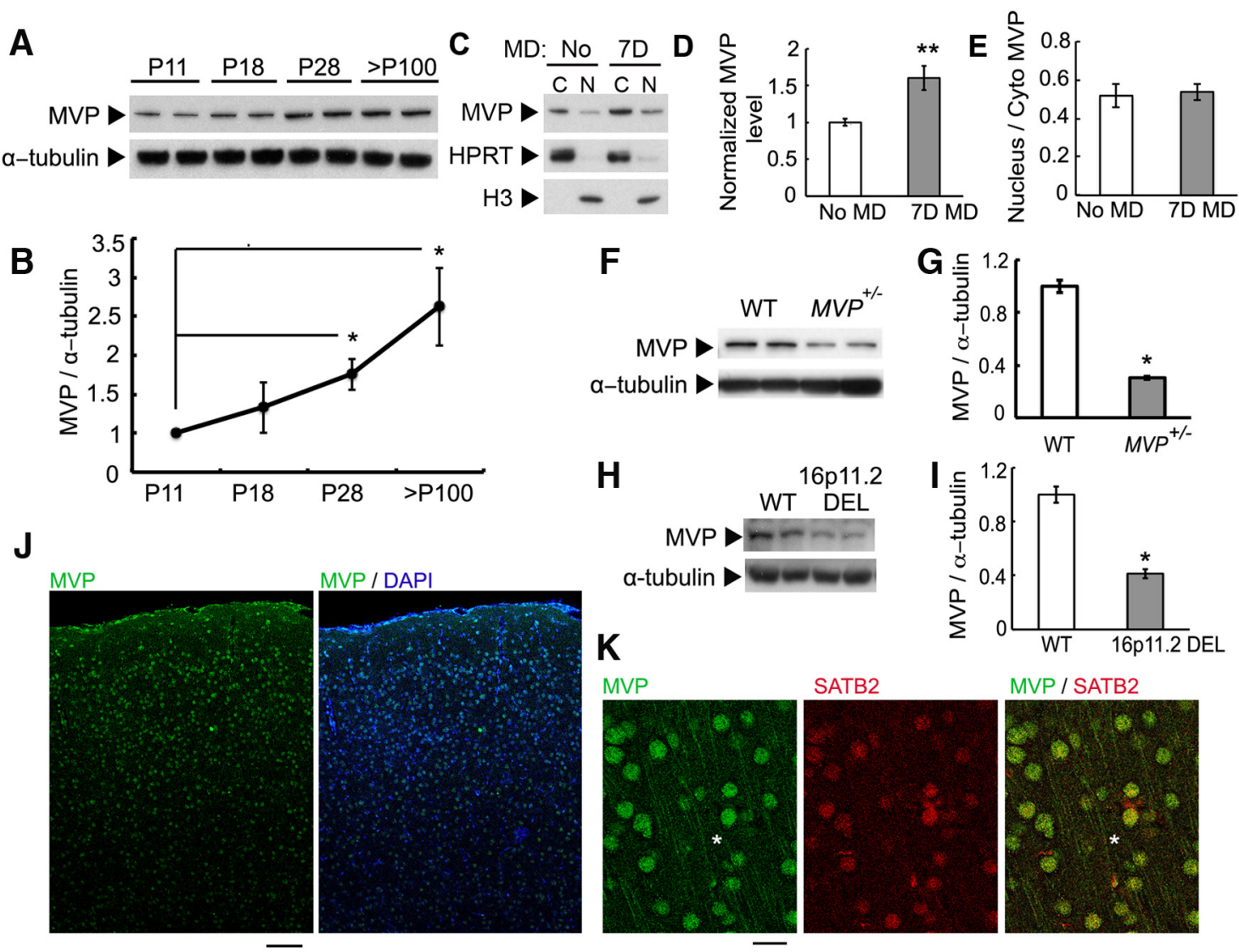

$16 \mathrm{p} 11.2$
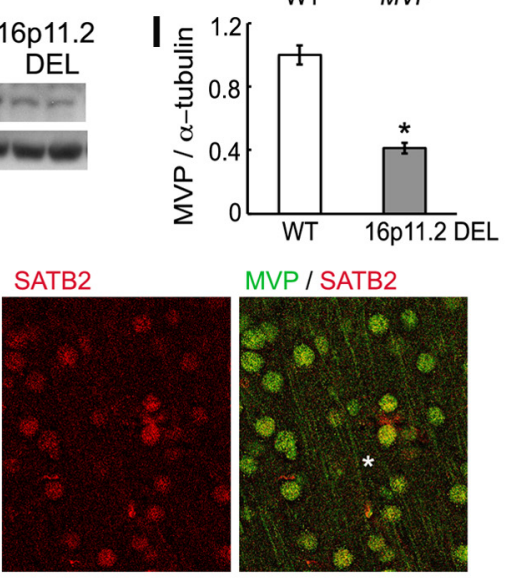

Figure 1. Expression of MVP proteins in cerebral cortex. $A, B$, Expression of MVP proteins during development and its quantification (normalized to P11; $n=3$ animals for each time point). C, Expression of MVP in cytoplasm and nucleus after $7 \mathrm{~d}$ MD. HPRT and histone H3 served as cytosolic and nuclear markers, respectively. Lysates were collected from P35 animals. D, Quantification of MVP level after $7 \mathrm{dMD}$ ( $n=5$ animals each). $\boldsymbol{E}$, Ratio of nuclear/cytosolic MVP proteins after $7 \mathrm{~d}$ MD. $\boldsymbol{F}, \mathbf{G}$, Expression of MVP in WT and MVP ${ }^{+/-}$mice and its quantification ( $n=3$ animals each). Lysates were collected from P30 animals. $\boldsymbol{H}, \mathbf{I}$, Expression of MVP in WT and 16p11.2 microdeletion mice and its quantification ( $n=3$ animals each). Lysates were collected from P30 animals.J, MVP is expressed across all cortical layers. Scale bar, $100 \mu \mathrm{m} . \boldsymbol{K}$, MVP is expressed in neurites (white asterisks) and nuclei. MVP is expressed in SATB2 + excitatory neurons ( $87 \pm 2 \%$ colocalization, $n=$ 3 animals). Scale bar, $25 \mu \mathrm{m}$. Averaged data are presented as mean \pm SEM. ${ }^{*} p<0.05,{ }^{* *} p<0.01$.

although $7 \mathrm{~d} \mathrm{MD}$ also led to significantly increased responses from the ipsilateral (open) eye ( $t$ test, $p=0.0111$; Fig. $2 B$ ); these results were consistent with previous findings (Sato and Stryker, 2008; McCurry et al., 2010; Nagakura et al., 2014). In $M V P^{+/-}$ mice, a decrease of closed-eye responses occurred, as in WT mice after $7 \mathrm{~d}$ MD ( $t$ test, $p=0.0046$; Fig. $2 B$ ). However, $M V P^{+/-}$mice exhibited no upregulation of ipsilateral, open-eye responses after $7 \mathrm{~d} \mathrm{MD}$ (Fig. 2B), and there was a significant difference in openeye responses between WT and $M V P^{+1-}$ mice after $7 \mathrm{~d} \mathrm{MD}$ ( $t$ test, $p=0.0022$ ).

Although both WT and $M V P^{+/-}$mice showed a significant reduction of ODI and a shift toward the open eye after $7 \mathrm{~d}$ MD (a two-way ANOVA yielded a main effect for the duration of $\mathrm{MD}$, $p=0.0001$; simple effects within WT, $p=0.0184$ for no MD vs $4 \mathrm{~d} \mathrm{MD}, p=0.0001$ for no $\mathrm{MD}$ vs $7 \mathrm{~d} \mathrm{MD}$ with Bonferroni correction; simple effects within $M V P^{+/-}, p=0.0326$ for no MD vs $7 \mathrm{~d} \mathrm{MD}$ with Bonferroni correction), there was a significant difference between ODIs for WT and $M V P^{+/-}$mice after $7 \mathrm{~d} \mathrm{MD}$ ( $p=0.0471$ between $7 \mathrm{~d}$ MD ODIs in WT and $M V P^{+/-}$with Bonferroni correction; Fig. 2C) because of the impaired open-eye responses in $\mathrm{MVP}^{+/-}$mice. These results thus suggest that MVP plays a critical role in the later component of OD plasticity mediated by homeostatic strengthening of open-eye responses within intracortical circuits.

Because the principal effect of MD in $M V P^{+/-}$mice is on the magnitude of ipsilateral eye responses, and the ipsilateral projec- tion from the retina is small compared with the contralateral projection, even small anatomical variations in the retinofugal projection in $\mathrm{MVP}^{+/-}$mice could have major effects on ipsilateral eye responses measured upstream in V1. We thus traced eye-specific projections to the dorsal LGN (dLGN) using intraocular injections of cholera toxin conjugated to Alexa (CTB-Alexa). We found no difference in retinal projections to the dLGN between the total ipsilateral areas or in overlap between contralateral and ipsilateral areas of WT and $M V P^{+/-}$mice (Fig. 2D-F).

\section{$M V P^{+/-}$mice show impaired synaptic responses after} longer-term MD

To examine the mechanism underlying impaired plasticity after $7 \mathrm{~d} \mathrm{MD}$ in $\mathrm{MVP}^{+/-}$mice, we recorded AMPAR-mediated mEPSCs from layer $2 / 3$ pyramidal neurons in the binocular region of V1. The mean values of the amplitude (one-way ANOVA, Tukey's test, $p=0.9636$ ) and frequency (one-way ANOVA, Tukey's test, $p=$ 0.8674 ) of mEPSCs were not significantly different between WT and $M V P^{+/-}$neurons at baseline without $\mathrm{MD}$ (Fig. $3 A, B$ ). After $7 \mathrm{~d} \mathrm{MD}$, the mEPSC amplitude of $M V P^{+/-}$neurons was significantly reduced compared with WT neurons (mean difference, $2.44 \pm 0.82 \mathrm{pA}$, one-way ANOVA, Tukey's test, $p=0.0266$ ). Cumulative probability distributions showed that whereas mEPSC amplitudes increased with $7 \mathrm{~d}$ in WT neurons, they decreased in $\mathrm{MVP}^{+/-}$neurons with $7 \mathrm{~d} \mathrm{MD}$ and the two populations were significantly different (Fig. 3B, left; Kolmogorov- 
A

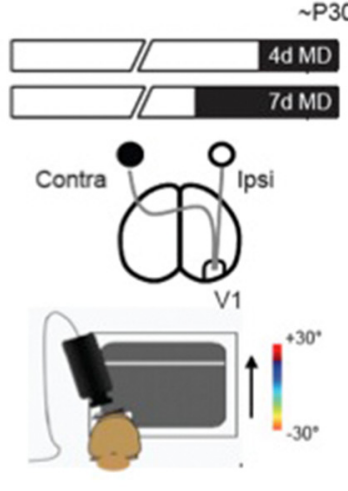

B

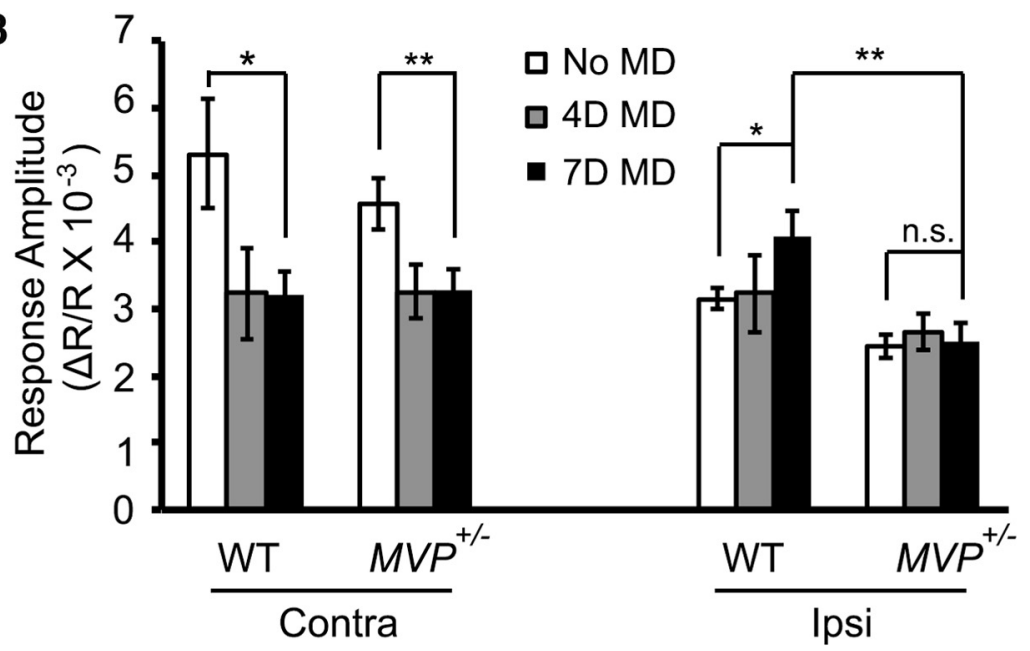

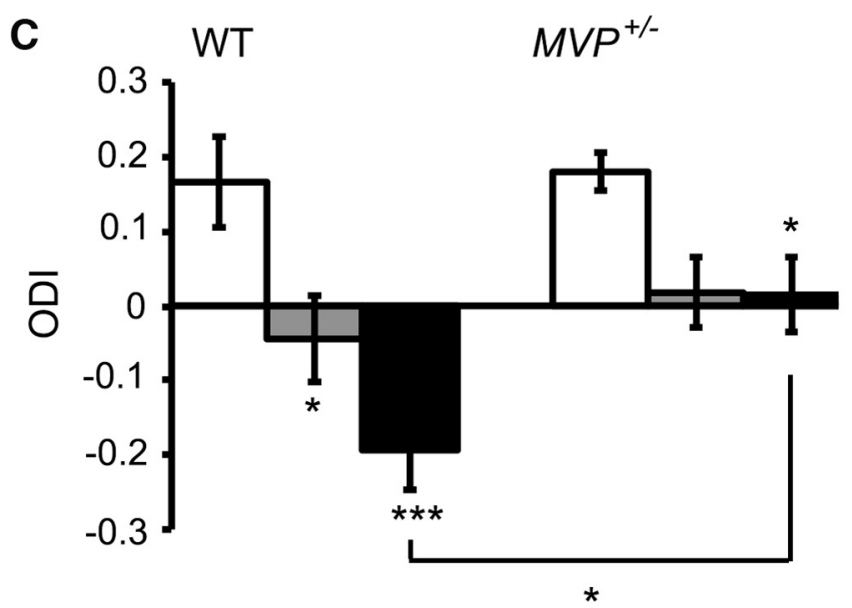

D
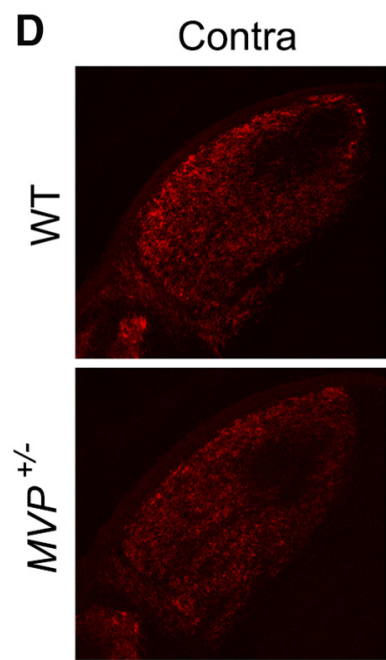

Ipsi
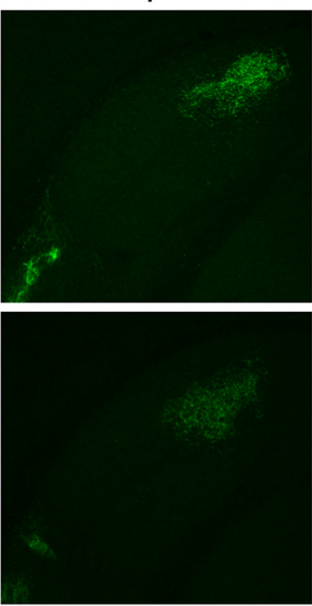

Merged
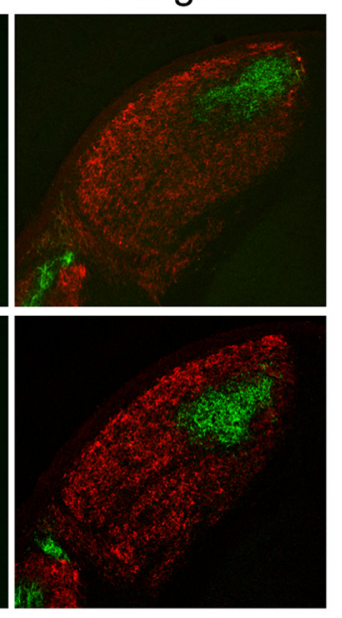

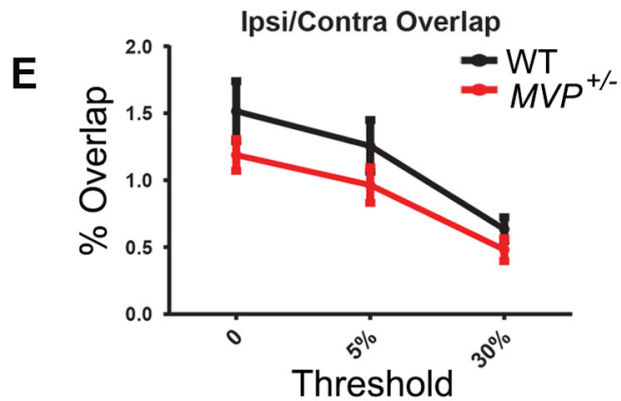

F

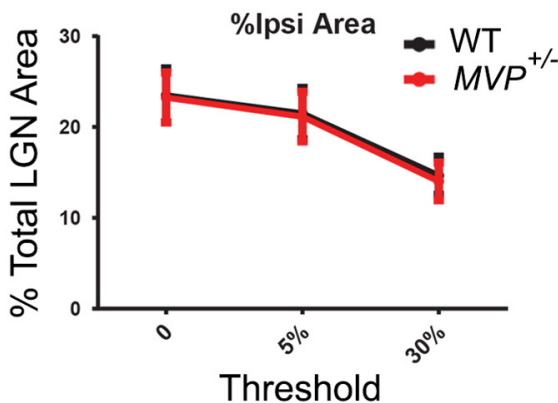

Figure 2. $M V P^{+/-}$mice show impaired open-eye responses and reduced OD plasticity after $7 \mathrm{~d} M D$. $A$, Schematic of optical imaging experiments in $\mathrm{V} 1$ in response to stimulation of the contralateral (Contra) and ipsilateral (Ipsi) eyes. B, Quantification of the response amplitude in V1 for the contralateral and ipsilateral eyes after $4 \mathrm{~d}$ or $7 \mathrm{~d} \mathrm{MD}$ of the contralateral eye during the critical period (WT no MD, $4 \mathrm{dMD}$, and $7 \mathrm{dMD}, n=5,6$, and 5 animals, respectively; $M V P^{+/-}$no MD, $4 \mathrm{~d} \mathrm{MD}$, and $7 \mathrm{~d} M D, n=6,5$, and 6 animals, respectively). C, ODI values in WT and $M V P^{+/-}$mice. $\boldsymbol{D}$, Representative images of dLGN contralateral (red) and ipsilateral (green) eye fields, and merged images, from WT and $M V P^{+1-}$ mice. Scale bar, $100 \mu \mathrm{m}$. $\boldsymbol{E}, 0$ verlap percentage between ipsilateral and contralateral areas in the LGN. F, Ipsilateral percentage of the total dLGN area. WT, MVP ${ }^{+/-}, n=3$ animals each. Averaged data are presented as mean $\pm S E M .{ }^{*} p<0.05,{ }^{* *} p<$ $0.01,{ }^{* * *} p<0.001$. 
A

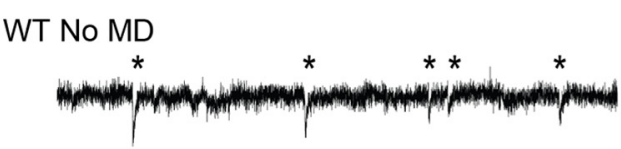

WT 7D MD

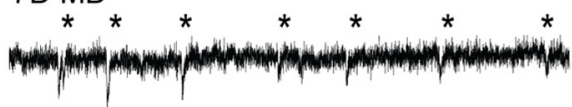

B

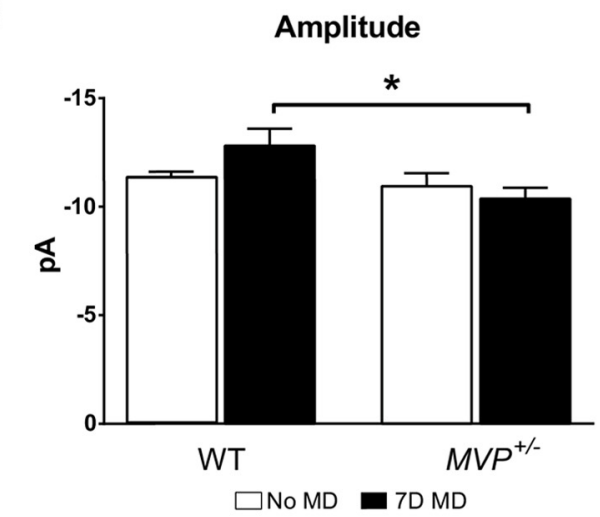

Amplitude

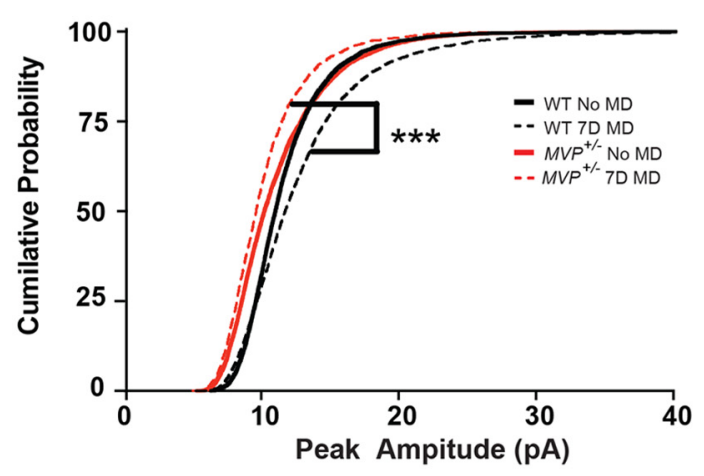

C

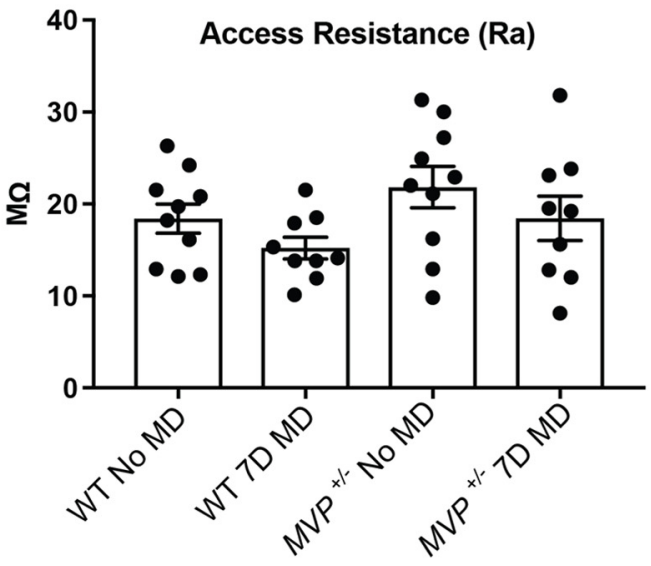

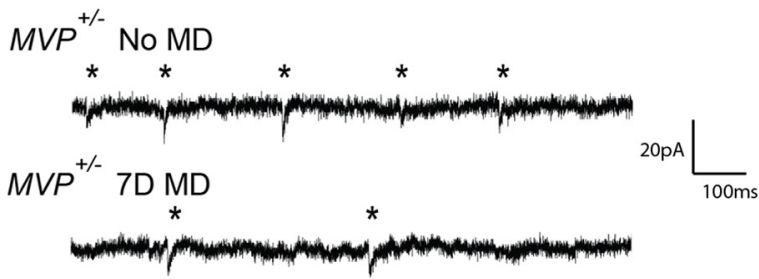

mEPSC Frequency
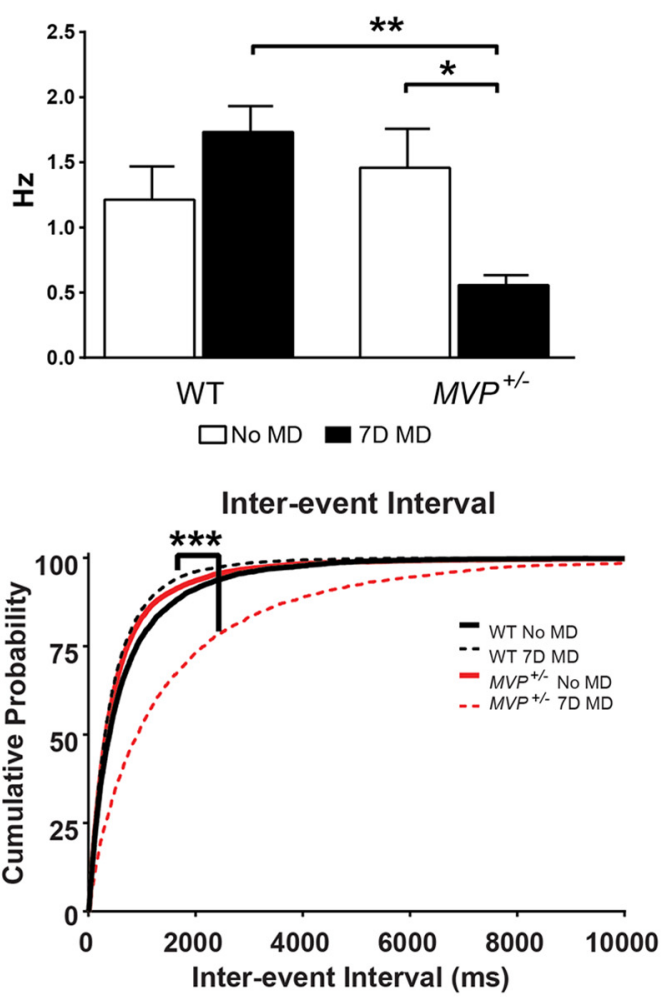

D

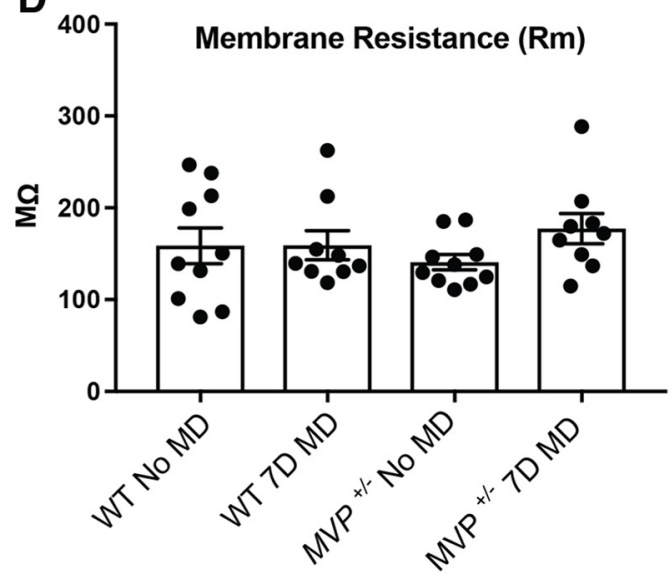

Figure 3. $M V P^{+/-}$mice show impaired homeostatic scaling of AMPAR-mediated mEPSCs after $7 \mathrm{dMD} . A$, Representative traces of AMPAR-mediated mEPSCs recorded in V1 slices from WT and $M V P^{+/-}$ mice, in No MD and $7 \mathrm{~d}$ MD conditions. Each asterisk shows an individual mEPSC. B, Left, Top, Average peak amplitudes for mEPSCs. Bottom, Cumulative probabilities of $\mathrm{mEPSC}$ peak amplitudes. Right, Top, Average mEPSC frequencies. Bottom, Cumulative probabilities of mEPSC interevent intervals. WT No MD and $7 \mathrm{dMD}, n=10$ (5) and 9 (4) (ells (animals), respectively; $M V P^{+/-}$No MD and $7 \mathrm{~d} \mathrm{MD,} n=10$ (3) and 9 (3) cells (animals), respectively. $\boldsymbol{C}$, Access resistance and (D) membrane resistance of the neurons examined. Averaged data are presented as mean \pm SEM. ${ }^{*} p<0.05,{ }^{* *} p<0.01,{ }^{* * *} p<0.001$.

Smirnov test, $p=0.0001)$. Additionally, there was a trend toward an increase in the frequency of mEPSCs with $7 \mathrm{~d} M D$ in WT neurons (Fig. 3B, right; one-way ANOVA, Tukey's test, $p=$ 0.3982). However, $M V P^{+/-}$neurons displayed a significant de- crease in frequency compared with both WT $7 \mathrm{~d}$ MD (mean difference, $1.18 \mathrm{~Hz}$, one-way ANOVA, Tukey's test, $p=0.0068$ ) and $\mathrm{MVP}^{+/-}$No MD (mean difference, $0.90 \mathrm{~Hz}$, one-way ANOVA, Tukey's test, $p=0.0441$ ). Cumulative probability dis- 


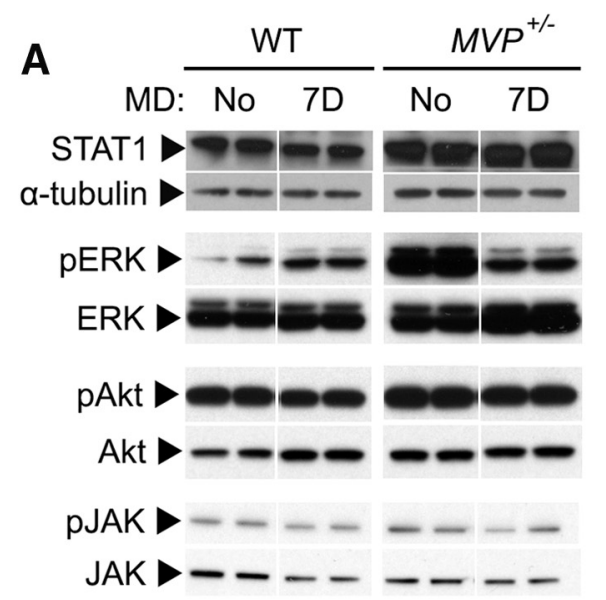

B
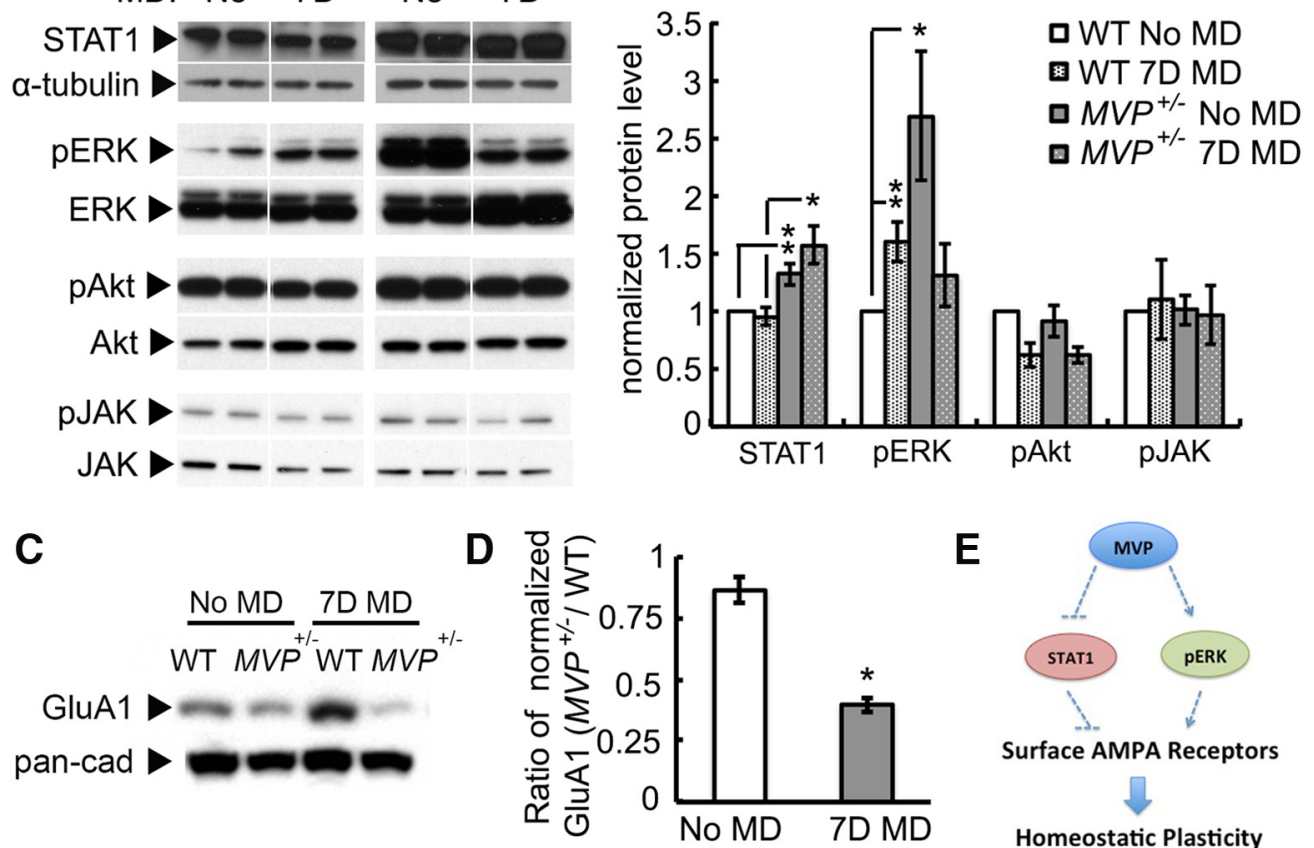

$\square M V P^{+/} 7 \mathrm{D} M D$

Figure 4. Altered signaling pathways and AMPAR surface expression in $M V P^{+/-}$mice. $A, B$, Expression of signaling proteins and its quantification in WT and $M V P^{+/-}$mice, in No MD and $7 \mathrm{~d}$ MD conditions. Lysates were collected from P32-P35 animals. WT, MVP ${ }^{+/-}, n=4-6$ animals for each condition. C, Cell surface expression of GluA1 in WT and MVP ${ }^{+/-}$mice. Lysates were collected from P32-P35 animals. D, Quantification of surface GluA1 ratio in $M V P^{+/-}$and WT mice, in No MD and $7 \mathrm{~d} \mathrm{MD} \mathrm{conditions} \mathrm{(} n=3$ animals each). Averaged data are presented as mean \pm SEM. ${ }^{*} p<0.05,{ }^{* *} p<0.01$. E, Hypothesis that MVP regulates STAT1 and ERK activity, which in turn regulate surface AMPARs, to enable homeostatic plasticity.

tributions of mEPSC interevent intervals showed that the distribution in WT neurons shifted toward shorter interevent intervals with $7 \mathrm{~d} \mathrm{MD}$, while $M V \mathrm{P}^{+/-}$neurons displayed significantly longer interevent intervals (Kolmogorov-Smirnov test, $p=0.0001$ ). No significant change in access resistance (Fig. $3 C$ ) and membrane resistance (Fig. 3D) was observed between experimental groups. Collectively, the analysis of mEPSCs indicates that MVP reduction critically alters synaptic properties of neurons in binocular $\mathrm{V} 1$ in response to extended MD.

$M V P^{+/-}$mice show enhanced expression of STAT1, dysregulated activation of ERK, and impaired AMPAR surface expression after MD

MVP has been shown to regulate multiple signaling pathways including the ERK and JAK/STAT pathways (Kolli et al., 2004; Kim et al., 2006; Steiner et al., 2006; Berger et al., 2009). To determine possible molecular mechanisms of MVP-mediated homeostatic responses following MD, we next measured components of intracellular signaling in WT and $M V P^{+/-}$mice. We probed protein levels of a panel of molecules, including STAT1, pERK, pAkt, and pJAK. These molecules were selected based on their known involvement with MVP signaling and regulation of cortical plasticity, or known involvement in 16p11.2 pathophysiology (Yu et al., 2002; Kim et al., 2006; Steiner et al., 2006; Golzio et al., 2012; Pucilowska et al., 2015).

We found that ERK activation and STAT1 expression were significantly altered in $\mathrm{MVP}^{+/-}$mice after $7 \mathrm{~d} \mathrm{MD}$, while activation of other molecules including, Akt and JAK were unaltered (Fig. 4A,B). ERK was hyperphosphorylated in $M V P^{+/-}$mice without MD ( $t$ test, $p=0.0131$, WT no MD vs $M V P^{+/-}$no MD; Fig. $4 B$ ) but the phosphorylation levels were decreased after $7 \mathrm{~d}$ $\mathrm{MD}$. On the contrary, pERK levels were significantly increased in
WT after $7 \mathrm{~d}$ MD ( $t$ test, $p=0.0025$, WT no MD vs WT $7 \mathrm{~d}$ MD; Fig. $4 B$ ). These results thus indicate dysregulation of pERK in $M V P^{+/-}$mice during OD plasticity. ERK signaling plays an important role in OD plasticity, likely through regulation of CRE-mediated gene expression (Di Cristo et al., 2001). Another protein that we found to be significantly increased was STAT1 (signal transducer and activator of transcription 1), a downstream molecule of JAK signaling. Enhanced STAT1 protein levels were observed in $M V P^{+/-}$mice compared with WT $(t$ test, $p=0.0069$, WT no MD vs $M V P^{+/-}$no MD; Fig. $\left.4 B\right)$. The expression of STAT1 in $M V P^{+/-}$mice stayed high after $7 \mathrm{~d} \mathrm{MD}$, whereas no significant change was observed in WT mice ( $t$ test, $p=0.0139$, WT $7 \mathrm{~d}$ MD vs $M V P^{+/-} 7 \mathrm{~d}$ MD; Fig. $\left.4 B\right)$. The increased expression of STAT1 in $M V P^{+/-}$mice suggested a role of MVP in inhibiting STAT1, consistent with other reports (Steiner et al., 2006). We have previously examined OD plasticity in STAT1 KO mice and shown that they have an accelerated increase in non-deprived (open) eye responses and enhanced OD plasticity after $4 \mathrm{~d}$ MD (Nagakura et al., 2014). Here we have shown that $M V P^{+/-}$mice have an opposite phenotype to STAT1 $\mathrm{KO}$ mice, viz. impairment in open-eye responses and reduced OD plasticity after $7 \mathrm{~d} \mathrm{MD}$ (Fig. $2 B, C$ ).

STAT1 signaling influences cortical plasticity by regulating cell surface GluA1 AMPAR expression (Nagakura et al., 2014); hence, impaired surface levels of GluA1 AMPARs may underlie the reduced plasticity in $M V P^{+/-}$mice. GluAl subunits have been shown to mediate open-eye potentiation in OD plasticity (Ranson et al., 2013; Nagakura et al., 2014). In hippocampal cultures, different AMPA subunit types including GluA1 can contribute to homeostatic plasticity (Altimimi and Stellwagen, 2013). Thus, we reasoned that surface GluA1 level is a faithful reporter of surface AMPA receptor levels that mediate feedback compensa- 
A
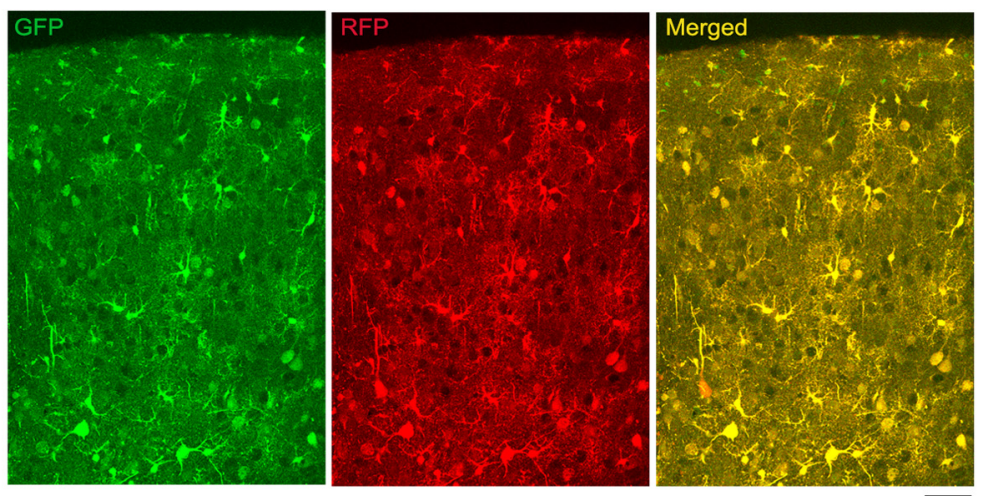

B

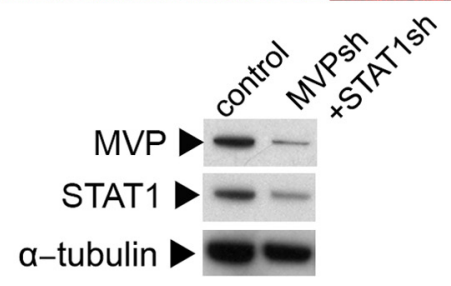

D

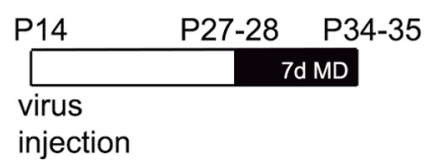

E

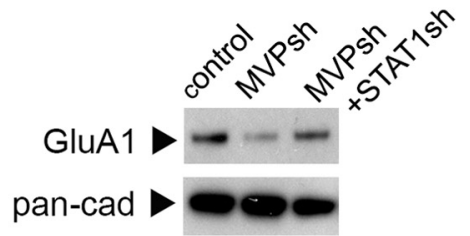

G

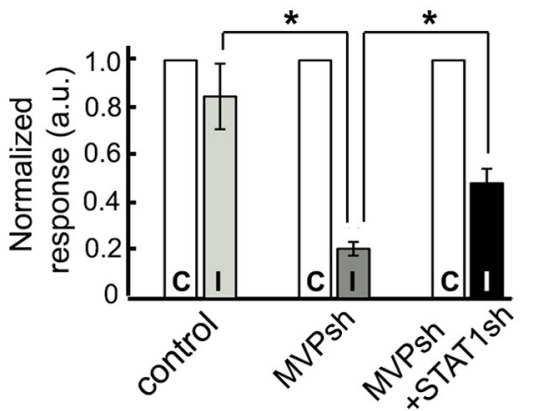

C

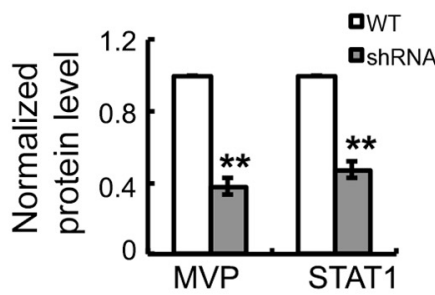

$\mathbf{F}$

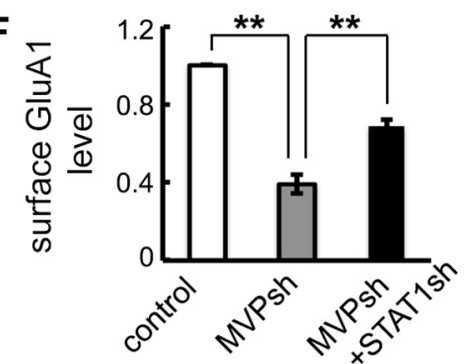

H

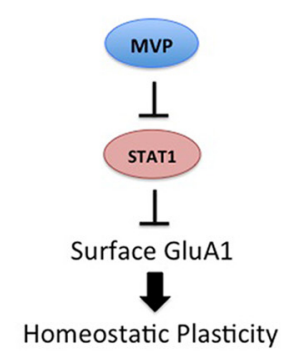

Figure 5. Normalization of STAT1 level partially rescues deficits in surface GluA1 expression and open-eye responses induced by MVP-knockdown after long-term MD. A, GFP and RFP expressed in virus-infected cells across cortical layers of mouse V1. Scale bar, $50 \mu \mathrm{m} . B, C$, Expression of MVP and STAT1 and its quantification in the visual cortex of mice injected with MVPsh and STAT1sh compared with control mice injected with GFP and $m$ Cherry-expressing viruses ( $n=3$ animals each). Lysates were collected from P35 animals. D, Timeline of virus injection and eyelid suture in the surface biotinylation assay and optical imaging experiment. $\boldsymbol{E}, \boldsymbol{F}$, Expression of cell surface GluA1 after 7d MD and its quantification in V1 of mice injected with scramble control, MVPsh or MVPsh + STAT1sh viruses ( $\mathrm{n}=3$ animals each). Lysates were collected from P35 animals. G, Quantification of the normalized ipsilateral open-eye response after $7 \mathrm{dMD}$ ( $n=3$ animals each). C, Contralateral eye response; I, ipsilateral eye response. Averaged data are presented as mean \pm SEM. ${ }^{*} p<0.05,{ }^{* *} p<0.01$. $\boldsymbol{H}$, Schematic summarizing data showing that MVP regulates STAT1 level, which in turn regulates surface GluA1 AMPAR subunits, to enable homeostatic plasticity.

tion after long-term (7 d) MD. We then investigated the role of MVP in regulating surface AMPAR using a surface-receptor biotinylation assay (Fig. 4C). Comparing the ratio of surface GluA1 in $M V P^{+/-}$mice to that in WT mice in no MD and $7 \mathrm{~d} \mathrm{MD}$ conditions (Fig. 4D), we found a significantly lowered ratio after $7 \mathrm{~d}$ MD compared with no MD ( $t$ test, $p=0.0211$, No MD vs $7 \mathrm{~d}$ MD; Fig. $4 D$ ). These results are consistent with the proposal that GluA1 surface insertion mediates open-eye potentiation, and reduced ho- meostatic GluA1 insertion likely contributes to impaired synaptic AMPAR function in $M V P^{+l-}$ mice, which may underlie the reduced open-eye potentiation and $\mathrm{OD}$ plasticity in these mice (Fig. $4 E$ ).

\section{Normalization of STAT1 level partially rescues deficits in surface GluA1 expression and open-eye responses induced by MVP-knockdown after long-term MD}

To demonstrate a mechanistic link between MVP, STAT1, GluA1 surface expression, and OD plasticity, we examined whether normalization of STAT1 level by introducing STAT1 shRNA (STAT1sh) could rescue the surface GluA1 deficit generated by MVP deficiency after $7 \mathrm{~d}$ MD. To achieve this, we injected either validated scramble control virus, MVP shRNA (MVPsh) virus alone, or combination of MVPsh and STAT1sh (MVPsh+STAT1sh) virus into the binocular zone of $\mathrm{V} 1$ at $\mathrm{P} 14$ and performed eyelid suture on P27-P28 (Fig. 5D). The AAV constructs carrying MVPsh and STAT1sh expressed GFP and RFP respectively, allowing for visualization of viral expression in the cortex (Fig. $5 A)$. Significant knockdown of MVP $(t$ test, $p=0.0060)$ and STAT1 ( $t$ test, $p=$ 0.0071 ) was achieved (Fig. $5 B, C$ ). Injection of the vectors led to robust coexpression of GFP and RFP in neurons across cortical layers after 20-21 d (Fig. 5A). We then examined surface GluA1 expression in the experimental mice. We found that dampening of STAT1 level was sufficient, at least partially, to restore surface GluA1 level in MVP-knockdown V1 cortex after $7 \mathrm{~d} \mathrm{MD}(p=0.0058$ between $7 \mathrm{~d} \mathrm{MD}$ in control and MVPsh; $p=0.0084$ between $7 \mathrm{~d}$ MD in MVPsh and MVPsh+ STAT1sh; Fig. 5F). To examine whether a functional rescue of impaired plasticity can be achieved by STAT1 normalization, we performed optical imaging after $7 \mathrm{~d}$ $\mathrm{MD}$ to record intrinsic signals from the binocular region of V1. Because changes in GluA1 surface expression (Fig. $5 F$ ) after $7 \mathrm{~d}$ MD largely represent changes in synaptic strength from the ipsilateral, open eye, we examined the parallel changes that would be expressed in ipsilateral open-eye responsesnormalizedtocontralateralclosedeye responses (Fig. 5G). Modulation of STAT1 level by shRNA partially rescued the open-eye response deficit induced by MVP-knockdown after $7 \mathrm{~d}$ MD $(t$ test; $p=$ 0.0287 between $7 \mathrm{~d}$ MD in control and MVPsh; $p=0.0206$ between $7 \mathrm{~d}$ MD in MVPsh and MVPsh+STAT1sh; no significant difference between control and MVPsh+STAT1sh; Fig. 5G). Together, these findings suggest that the MVP-regulated STAT1 level is a crucial molecular mechanism that controls surface GluA1 expression and OD plasticity (Fig. $5 H$ ). 


\section{Discussion}

MVP has been studied in various cellular systems and species (see Introduction). However, studies of its functional role in the CNS are limited. In this study, we have identified MVP as an important regulator of the homeostatic component of experience-dependent plasticity in the visual cortex. $M V P^{+/-}$mice showed impairment in strengthening of open-eye responses in V1 after $7 \mathrm{~d} \mathrm{MD}$, whereas closed-eye responses were weakened as normal, resulting in reduced overall OD plasticity. OD plasticity is considered to involve two separable processes: a Hebbian feedforward reduction of activity in closed-eye responses and a homeostatic feedback upregulation of open-eye responses (Turrigiano and Nelson, 2004; Tropea et al., 2009b; Espinosa and Stryker, 2012). Plasticity after 4 d MD was normal in $\mathrm{MVP}^{+/-}$mice, suggesting that impairment was specific to the later component of plasticity mediated by open-eye responses. Electrophysiological experiments showed that the frequency of mEPSCs was decreased in $\mathrm{MVP}^{+/-}$mice after $7 \mathrm{~d} \mathrm{MD}$, suggesting a decrease in the number of functional synapses. Indeed, we found reduced cell surface GluA1 AMPARs after 7 d MD in these mice. The GluA1 deficit and the impairment of open-eye responses were confirmed after MVP knockdown, and both were restored after concurrent knockdown of STAT1. Together, these findings link multiple mechanisms of OD plasticity, and suggest a specific role for MVP as a critical molecule in the homeostatic component of activity-dependent synaptic plasticity.

Two mouse models of 16p11.2 deletion syndrome have been independently generated (Horev et al., 2011; Portmann et al., 2014). These mice exhibit a range of common behavioral phenotypes, including circling behavior, hyperactivity, deficits in contextual conditioning, passive avoidance, and novel object recognition. Analyses of these 16p11.2 deletion mice have suggested multiple potential disease mechanisms, including aberrant cortical progenitor proliferation (Pucilowska et al., 2015), molecular and cellular abnormalities in the cortex and striatum, along with altered synaptic scaling and circuit defects in the basal ganglia (Portmann et al., 2014), and altered hippocampal LTD (Tian et al., 2015). These findings suggest that there is unlikely to be one central neural mechanism that explains the pathophysiology of 16 p11.2 deletion syndrome. However, dysregulation of synaptic plasticity is likely an important contributor to the pathophysiology of $16 \mathrm{p} 11.2$ microdeletion mice, and our study suggests this phenotype is shared with $M V P^{+/-}$mice. We further suggest that impaired homeostatic machinery resulting in dysfunction during experience-dependent circuit refinement may be a common mechanism for 16p11.2 microdeletion syndrome and other forms of autism (Nelson and Valakh, 2015). Indeed, previous studies have demonstrated that depletion of FMRP (in fragile X syndrome model mice) or MeCP2 (in Rett syndrome model mice) results in defects in various forms of synaptic plasticity including homeostatic synaptic scaling (Tropea et al., 2009a; Blackman et al., 2012; Sidorov et al., 2013; Castro et al., 2014; Della Sala and Pizzorusso, 2014).

MVP has been suggested to act as a multifaceted signaling platform for intracellular signal transduction (Berger et al., 2009). We found reduced levels of surface GluA1 AMPARs in $\mathrm{MVP}^{+/-}$mice after extended MD, accompanied by increased expression of STAT1 and dysregulated ERK signaling. STAT1, an immune molecule reported to be inhibited by MVP (Steiner et al., 2006), is a negative regulator of plasticity during the critical period $(\mathrm{Na}-$ gakura et al., 2014). Here we demonstrate that $M V P^{+/-}$mice exhibit an opposite plasticity effect to STAT1 depletion (Nagakura et al., 2014). These results are in agreement with the pro- posal that STAT1 acts downstream of MVP to regulate OD plasticity and MVP functions to negatively regulate STAT1. Consistently, whereas mice lacking STAT1 show increased surface AMPAR expression and function (Nagakura et al., 2014), reduced surface AMPAR expression is observed in V1 of $M V P^{+/-}$mice after $7 \mathrm{~d}$ MD. In addition, normalization of STAT1 level is sufficient, at least partially, to restore surface GluA1 expression and open-eye responses in MVP-knockdown V1 cortex after $7 \mathrm{~d}$ MD, demonstrating a mechanistic link between MVP, STAT1, GluA1 surface expression, and OD plasticity (Fig. 5E-G). Phosphorylation of ERK is important for OD plasticity, likely through CRE-mediated gene expression (Di Cristo et al., 2001). MVP has been shown to interact with ERK upon EGF stimulation and function as a scaffold to regulate function of ERK (Kolli et al., 2004; Kim et al., 2006). We report here that phosphorylation of ERK is dysregulated in $M V P^{+/-}$mice. Interestingly, abnormal ERK activity is also observed in the developing cortex and hippocampus of $16 \mathrm{p} 11.2 \mathrm{mi}-$ crodeletion mice (Pucilowska et al., 2015). Collectively, our findings point to a mechanism whereby MVP regulates STAT1 as well as ERK signaling (Figs. $4 E, 5 H$ ), which then increases GluA1 surface expression during homeostatic plasticity.

Subcellular fractionation experiments have revealed substantial amounts of MVP in both cytoplasm and nuclei of mammalian cells (Steiner et al., 2006; Paspalas et al., 2009), suggesting a potential role for vault-based shuttle function between cytoplasm and nucleus. Consistent with this idea, MVP has been found to mediate nuclear import of the tumor-suppressor molecule PTEN (Yu et al., 2002; Minaguchi et al., 2006). MVP was also found to mediate nuclear translocation and functional phosphorylation of STAT1 (Steiner et al., 2006). Future studies are needed to examine whether MVP functions as nucleocytoplasmic transporter to mediate OD plasticity during the critical period.

Previous studies have shed light on the important roles for immune signaling in OD plasticity. Tumor necrosis factor $\alpha$ (TNF $\alpha)$ is one primary molecule required for the homeostatic stage of OD plasticity (Kaneko et al., 2008). TNF $\alpha$ KO mice show impaired open-eye potentiation after 5-6 d MD (Kaneko et al., 2008), a phenotype similar to $M V P^{+/-}$mice. Another immune molecule important for OD plasticity is major histocompatibility complex class I (MHC-I). MHC-I, a transmembrane cell-surface molecule with a role in cellular immune recognition, has been shown to negatively regulate OD plasticity. Deficiency of MHC-I genes or its receptor PirB (paired Ig-like receptor B) results in strengthened OD plasticity (Syken et al., 2006; Datwani et al., 2009). This is similar to the effect in STAT1 KO mice as previously reported (Nagakura et al., 2014). Together with the role of MVP described here, these studies suggest a broad role for neuro-immune interactions in normal and abnormal synaptic and circuit plasticity.

\section{References}

Altimimi HF, Stellwagen D (2013) Persistent synaptic scaling independent of AMPA receptor subunit composition. J Neurosci 33:11763-11767. CrossRef Medline

Bear MF (2003) Bidirectional synaptic plasticity: from theory to reality. Philos Trans R Soc Lond B Biol Sci 358:649-655. CrossRef Medline

Berger W, Steiner E, Grusch M, Elbling L, Micksche M (2009) Vaults and the major vault protein: novel roles in signal pathway regulation and immunity. Cell Mol Life Sci 66:43-61. CrossRef Medline

Blackman MP, Djukic B, Nelson SB, Turrigiano GG (2012) A critical and cell-autonomous role for MeCP2 in synaptic scaling up. J Neurosci 32: 13529-13536. CrossRef Medline

Blaker-Lee A, Gupta S, McCammon JM, De Rienzo G, Sive H (2012) Zebrafish homologs of genes within $16 \mathrm{p} 11.2$, a genomic region associated with brain disorders, are active during brain development, and include 
two deletion dosage sensor genes. Dis Model Mech 5:834-851. CrossRef Medline

Castro J, Garcia RI, Kwok S, Banerjee A, Petravicz J, Woodson J, Mellios N, Tropea D, Sur M (2014) Functional recovery with recombinant human IGF1 treatment in a mouse model of Rett syndrome. Proc Natl Acad Sci U S A 111:9941-9946. CrossRef Medline

Chung JH, Eng C (2005) Nuclear-cytoplasmic partitioning of phosphatase and tensin homologue deleted on chromosome 10 (PTEN) differentially regulates the cell cycle and apoptosis. Cancer Res 65:8096-8100. CrossRef Medline

Chung JH, Ginn-pease ME, Eng C (2005) Phosphatase and tensin homologue deleted on chromosome 10 (PTEN) has nuclear localization signal-like sequences for nuclear import mediated by major vault protein. Cancer Res 65:4108-4116. CrossRef Medline

Cooke SF, Bear MF (2014) How the mechanisms of long-term synaptic potentiation and depression serve experience-dependent plasticity in primary visual cortex. Philos Trans R Soc Lond B Biol Sci 369:20130284. CrossRef Medline

Crepel A, Steyaert J, De la Marche W, De Wolf V, Fryns J-P, Noens I, Devriendt K, Peeters H (2011) Narrowing the critical deletion region for autism spectrum disorders on 16p11.2. Am J Med Genet Part B Neuropsychiatr Genet 156:243-245. CrossRef Medline

Datwani A, McConnell MJ, Kanold PO, Micheva KD, Busse B, Shamloo M, Smith SJ, Shatz CJ (2009) Classical MHCI molecules regulate retinogeniculate refinement and limit ocular dominance plasticity. Neuron 64: 463-470. CrossRef Medline

Della Sala G, Pizzorusso T (2014) Synaptic plasticity and signaling in Rett syndrome. Dev Neurobiol 74:178-196. CrossRef Medline

Di Cristo G, Berardi N, Cancedda L, Pizzorusso T, Putignano E, Ratto GM, Maffei L (2001) Requirement of ERK activation for visual cortical plasticity. Science 292:2337-2340. CrossRef Medline

Espinosa JS, Stryker MP (2012) Development and plasticity of the primary visual cortex. Neuron 75:230-249. CrossRef Medline

Fernandez BA, Roberts W, Chung B, Weksberg R, Meyn S, Szatmari P, Joseph-George AM, Mackay S, Whitten K, Noble B, Vardy C, Crosbie V, Luscombe S, Tucker E, Turner L, Marshall CR, Scherer SW (2010) Phenotypic spectrum associated with de novo and inherited deletions and duplications at 16p11.2 in individuals ascertained for diagnosis of autism spectrum disorder. J Med Genet 47:195-203. CrossRef Medline

Frenkel MY, Bear MF (2004) How monocular deprivation shifts ocular dominance in visual cortex of young mice. Neuron 44:917-923. CrossRef Medline

Gainey MA, Hurvitz-Wolff JR, Lambo ME, Turrigiano GG (2009) Synaptic scaling requires the GluR2 subunit of the AMPA receptor. J Neurosci 29:6479-6489. CrossRef Medline

Golzio C, Willer J, Talkowski ME, Oh EC, Taniguchi Y, Jacquemont S, Reymond A, Sun M, Sawa A, Gusella JF, Kamiya A, Beckmann JS, Katsanis N (2012) KCTD13 is a major driver of mirrored neuroanatomical phenotypes of the 16p11.2 copy number variant. Nature 485:363-367. CrossRef Medline

Gordon JA, Stryker MP (1996) Experience-dependent plasticity of binocular responses in the primary visual cortex of the mouse. J Neurosci 16: 3274-3286. Medline

Hanson E, Bernier R, Porche K, Jackson FI, Goin-Kochel RP, Snyder LG, Snow AV, Wallace AS, Campe KL, Zhang Y, Chen Q, D'Angelo D, Moreno-De-Luca A, Orr PT, Boomer KB, Evans DW, Kanne S, Berry L, Miller FK, Olson J, et al. (2015) The cognitive and behavioral phenotype of the $16 \mathrm{p} 11.2$ deletion in a clinically ascertained population. Biol Psychiatry 77:785-793. CrossRef Medline

Hensch TK (2005) Critical period plasticity in local cortical circuits. Nat Rev Neurosci 6:877-888. CrossRef Medline

Horev G, Ellegood J, Lerch JP, Son YE, Muthuswamy L, Vogel H, Krieger AM, Buja A, Henkelman RM, Wigler M, Mills AA (2011) Dosage-dependent phenotypes in models of 16p11.2 lesions found in autism. Proc Natl Acad Sci U S A 108:17076-17081. CrossRef Medline

Huang Y, Song NN, Lan W, Hu L, Su CJ, Ding YQ, Zhang L (2013) Expression of transcription factor Satb2 in adult mouse brain. Anat Rec (Hoboken) 296:452-461. CrossRef Medline

Hubel DH, Wiesel TN (1970) The period of susceptibility to the physiological effects of unilateral eye closure in kittens. J Physiol 206:419-436. CrossRef Medline

Kaneko M, Stellwagen D, Malenka RC, Stryker MP (2008) Tumor necrosis factor-alpha mediates one component of competitive, experience-dependent plasticity in developing visual cortex. Neuron 58:673-680. CrossRef Medline

Kim E, Lee S, Mian MF, Yun SU, Song M, Yi KS, Ryu SH, Suh PG (2006) Crosstalk between src and major vault protein in epidermal growth factor-dependent cell signalling. FEBS J 273:793-804. CrossRef Medline

Kolli S, Zito CI, Mossink MH, Wiemer EA, Bennett AM (2004) The major vault protein is a novel substrate for the tyrosine phosphatase SHP-2 and scaffold protein in epidermal growth factor signaling. J Biol Chem 279: 29374-29385. CrossRef Medline

Malhotra D, Sebat J (2012) CNVs: harbingers of a rare variant revolution in psychiatric genetics. Cell 148:1223-1241. CrossRef Medline

McCurry CL, Shepherd JD, Tropea D, Wang KH, Bear MF, Sur M (2010) Loss of arc renders the visual cortex impervious to the effects of sensory experience or deprivation. Nat Neurosci 13:450-457. CrossRef Medline

Minaguchi T, Waite KA, Eng C (2006) Nuclear localization of PTEN is regulated by $\mathrm{Ca}^{2+}$ through a tyrosil phosphorylation-independent conformational modification in major vault protein. Cancer Res 66:1167711682. CrossRef Medline

Mossink MH, van Zon A, Fränzel-Luiten E, Schoester M, Kickhoefer VA, Scheffer GL, Scheper RJ, Sonneveld P, Wiemer EA (2002) Disruption of the murine major vault protein (MVP/LRP) gene does not induce hypersensitivity to cytostatics. Cancer Res 62:7298-7304. Medline

Mossink MH, de Groot J, van Zon A, Fränzel-Luiten E, Schoester M, Scheffer GL, Sonneveld P, Scheper RJ, Wiemer EA (2003a) Unimpaired dendritic cell functions in MVP/LRP knockout mice. Immunology 110:5865. CrossRef Medline

Mossink MH, van Zon A, Scheper RJ, Sonneveld P, Wiemer EA (2003b) Vaults: a ribonucleoprotein particle involved in drug resistance? Oncogene 22:7458-7467. CrossRef Medline

Nagakura I, Van Wart A, Petravicz J, Tropea D, Sur M (2014) STAT1 regulates the homeostatic component of visual cortical plasticity via an AMPA receptor-mediated mechanism. J Neurosci 34:10256-10263. CrossRef Medline

Nelson SB, Valakh V (2015) Excitatory/inhibitory balance and circuit homeostasis in autism spectrum disorders. Neuron 87:684-698. CrossRef Medline

Pan HC, Lin JF, Ma LP, Shen YQ, Schachner M (2013) Major vault protein promotes locomotor recovery and regeneration after spinal cord injury in adult zebrafish. Eur J Neurosci 37:203-211. CrossRef Medline

Paspalas CD, Perley CC, Venkitaramani DV, Goebel-Goody SM, Zhang Y, Kurup P, Mattis JH, Lombroso PJ (2009) Major vault protein is expressed along the nucleus-neurite axis and associates with mRNAs in cortical neurons. Cereb Cortex 19:1666-1677. CrossRef Medline

Peng N, Liu S, Xia Z, Ren S, Feng J, Jing M, Gao X, Wiemer EA, Zhu Y (2016) Inducible major vault protein plays a pivotal role in double-stranded RNA- or virus-induced proinflammatory response. J Immunol 196:27532766. CrossRef Medline

Portmann, Yang M, Mao R, Panagiotakos G, Ellegood J, Dolen G, Bader PL, Grueter BA, Goold C, Fisher E, Clifford K, Rengarajan P, Kalikhman D, Loureiro D, Saw NL, Zhengqui Z, Miller MA, Lerch JP, Henkelman M, Shamloo M, et al. (2014) Behavioral abnormalities and circuit defects in the basal ganglia of a mouse model of $16 \mathrm{p} 11.2$ deletion syndrome. Cell Rep 7:1077-1092. CrossRef Medline

Pucilowska J, Vithayathil J, Tavares EJ, Kelly C, Karlo JC, Landreth GE (2015) The 16p11.2 deletion mouse model of autism exhibits altered cortical progenitor proliferation and brain cytoarchitecture linked to the ERK MAPK pathway. J Neurosci 35:3190-3200. CrossRef Medline

Pulimood NS, Rodrigues WD Jr, Atkinson DA, Mooney SM, Medina AE (2017) The role of CREB, SRF, and MEF2 in activity-dependent neuronal plasticity in the visual cortex. J Neurosci 37:6628-6637. CrossRef Medline

Qiu Z, Sylwestrak EL, Lieberman DN, Zhang Y, Liu XY, Ghosh A (2012) The Rett syndrome protein MeCP2 regulates synaptic scaling. J Neurosci 32: 989-994. CrossRef Medline

Ranson A, Sengpiel F, Fox K (2013) The role of GluA1 in ocular dominance plasticity in the mouse visual cortex. J Neurosci 33:15220-15225. CrossRef Medline

Sahin M, Sur M (2015) Genes, circuits, and precision therapies for autism and related neurodevelopmental disorders. Science 350:aab3897. CrossRef Medline

Sato M, Stryker MP (2008) Distinctive features of adult ocular dominance plasticity. J Neurosci 28:10278-10286. CrossRef Medline 
Sidorov MS, Auerbach BD, Bear MF (2013) Fragile X mental retardation protein and synaptic plasticity. Mol Brain 6:15. CrossRef Medline

Steiner E, Holzmann K, Pirker C, Elbling L, Micksche M, Sutterlüty H, Berger $\mathrm{W}$ (2006) The major vault protein is responsive to and interferes with interferon-gamma-mediated STAT1 signals. J Cell Sci 119:459-469. CrossRef Medline

Sur M, Nagakura I, Chen N, Sugihara H (2013) Mechanisms of plasticity in the developing and adult visual cortex. Prog Brain Res 207:243-254. CrossRef Medline

Syken J, GrandPre T, Kanold PO, Shatz CJ (2006) PirB restricts oculardominance plasticity in visual cortex. Science 313:1795-1800. CrossRef Medline

Tian D, Stoppel LJ, Heynen AJ, Lindemann L, Jaeschke G, Mills AA, Bear MF (2015) Contribution of mGluR5 to pathophysiology in a mouse model of human chromosome 16p11.2 microdeletion. Nat Neurosci 18:182-184. CrossRef Medline

Tropea D, Giacometti E, Wilson NR, Beard C, McCurry C, Fu DD, Flannery R, Jaenisch R. Sur M (2009a) Partial reversal of Rett syndrome-like symptoms in MeCP2 mutant mice. Proc Natl Acad Sci U S A 106:2029_ 2034. CrossRef Medline

Tropea D, Van Wart A, Sur M (2009b) Molecular mechanisms of experiencedependent plasticity in visual cortex. Philos Trans R Soc Lond B Biol Sci 364:341-355. CrossRef Medline

Turrigiano GG, Nelson SB (2004) Homeostatic plasticity in the developing nervous system. Nat Rev Neurosci 5:97-107. CrossRef Medline

Yu Z, Fotouhi-Ardakani N, Wu L, Maoui M, Wang S, Banville D, Shen SH (2002) PTEN associates with the vault particles in HeLa cells. J Biol Chem 277:40247-40252. CrossRef Medline 